\title{
Effects of nicomethanol hydrofluoride on dental enamel and synthetic apatites: a role for anti-caries protection
}

\author{
N. Sharkov ${ }^{1}$ (D)
}

Received: 20 January 2017 / Accepted: 22 September 2017/Published online: 4 November 2017

(c) The Author(s) 2017. This article is an open access publication

\begin{abstract}
Aim To analyse the anti-caries properties of nicomethanol hydrofluoride $(\mathrm{NH})$ and the benefit of its combination with siliglycol, a coating agent.

Methods Fluoride (F) uptake by dental enamel and synthetic apatite treated with $\mathrm{NH}$ was measured in vitro and compared to treatment with mineral fluorides. The addition of siliglycol was also tested. The effect of $\mathrm{NH}$ (as a mouthwash) on salivary $\mathrm{pH}$ was also investigated in healthy human subjects and compared to the effect of a placebo and of nicomethanol alone.

Results In vitro experiments showed a greater and faster $\mathrm{F}$ uptake on dental enamel or synthetic apatite treated with $\mathrm{NH}$ compared to sodium fluoride. F uptake was improved further by the addition of siliglycol. In healthy human subjects, $\mathrm{pH}$ reduction was strongly inhibited $5 \mathrm{~min}$ after two mouthrinses with NH. This effect was less pronounced but still statistically significant at 15 and $30 \mathrm{~min}$ $(\mathrm{p}<0.05)$.

Conclusions $\mathrm{NH}$ was able to promote the fixation of $\mathrm{F}$ ions and strengthen the dental structure. Its combination with siliglycol further improved $\mathrm{F}$ uptake by the tooth and the control/inhibition of dental biofilm development.
\end{abstract}

Keywords Fluorine $\cdot$ Fluorinol $^{\circledR} \cdot$ Dental caries . Siliglycol $\cdot$ Amine fluoride $\cdot$ Caries prevention

N. Sharkov

sharkov@omega.bg

1 Department of Paediatric Dental Medicine, Faculty of Dental Medicine, Medical University, Sofia, Bulgaria

\section{Introduction}

Despite a marked improvement in dental caries prevention over the last few decades, $60-90 \%$ of school children and nearly $100 \%$ of adults have dental cavities (Kimura et al. 1983). In 2020, the annual cost of dental treatment, most related to dental caries, is expected to rise to $€ 93$ billion within the member states of the European Union (Patel 2012).

Dental caries bears a significant medical, social and economic cost in children, being one of the frequent reasons for absence from school (Rugg-Gunn 2013), and the commonest reason for general anaesthesia in young children when tooth extraction is required (Banoczy and RuggGunn 2013). The prevalence and severity of dental caries, which vary widely within Europe, remains a problem in socio-economically deprived groups (Kimura et al. 1983; Markovic et al. 2013).

The use of fluoride (F) toothpaste is considered to be one of the main contributing factors for the decrease in dental caries prevalence in children in both developed and developing countries (Bratthall et al. 1996; Cury et al. 2004; Marinho 2009; Marinho et al. 2013; Rugg-Gunn and Banoczy 2013). Over 90\% of toothpastes sold in Europe are fluoridated (Rugg-Gunn and Banoczy 2013). Fluoride acts as an anti-caries agent by counterbalancing the mineral losses caused by acid production, mainly through the precipitation of fluoridated mineral components on teeth (Byeon et al. 2016; Lata et al. 2010; Tenuta and Cury 2010).

Various $\mathrm{F}$ compounds have been tested in $\mathrm{F}$ toothpastes, including amine $\mathrm{F}$, an organic $\mathrm{F}$ that is widely used in Europe (Rugg-Gunn and Banoczy 2013). The solubility of the F-containing compound and its adhesion to the tooth surface determines the bioavailability of $\mathrm{F}$, which is critical for caries prevention (ten Cate 1999; Galuscan et al. 2003; Priyadarshini et al. 2013; Carey 2014). 
Early work suggested that amine $\mathrm{F}$ was superior to mineral $\mathrm{F}$ for reducing the solubility of the enamel, improving its $\mathrm{F}$ content and preventing caries (Muhlemann et al. 1968; Cahen et al. 1982; Barbakow et al. 1983; Tadmor et al. 1989). Amine $\mathrm{F}$ has tension-active properties which increase the affinity of $F$ to the enamel surface and provide a sustained $\mathrm{F}$ release, allowing prolonged, longlasting action (Madlena 2013). In addition, amine F exerts an anti-plaque activity by inhibiting bacterial adhesion (Shani et al. 1996; Priyadarshini et al. 2013).

Nicomethanol hydrofluoride $(\mathrm{NH})$, which belongs to the amine $\mathrm{F}$ group, has a chemical/organic structure designed to improve the absorption of $\mathrm{F}$ by the phosphocalcic tooth surface. The reactivity of NH with tooth enamel and with a synthetic hydroxyapatite was first described (Szilagyi 1981). NH can be combined with siliglycol, a coating agent used in some toothpaste formulations to support $\mathrm{F}$ action.

The aims of the study were to investigate the intrinsic properties of $\mathrm{NH}$ alone and the benefit of its combination with a covering agent (siliglycol) for anti-caries protection.

\section{Materials and methods}

In vitro and in vivo investigations were conducted to study the intrinsic properties of NH, combined or not to siliglycol.

NH (trade name Fluorinol ${ }^{\circledR}$, Pierre Fabre Médicament, Castres, France) is an organic fluorine salt, belonging to the amine $\mathrm{F}$ group. This organic $\mathrm{F}$ possesses a fluoride ion $\left(\mathrm{F}^{-}\right)$ that is ionically bound to the rest of the molecule (Fig. 1).

Siliglycol, also called PG-12 Dimethicone, is a coating agent that belongs to a group of polymeric organosilicon compounds.

\section{In vitro investigations}

The absorption properties of $\mathrm{NH}$ on the surface of natural and synthetic apatites were investigated in two in vitro experiments. The addition of siliglycol to NH was considered in a third experiment.

\section{Calcium fluoride formation measurements were made using infrared spectroscopy}

F uptake was measured at the surface of dental enamel and synthetic apatites after treatment with $\mathrm{NH}$, sodium fluoride ( $\mathrm{NaF})$ or sodium chloride ( $\mathrm{NaCl}$, control solution). Two quantities of apatite were tested: 100 and $200 \mathrm{mg}$. The fluoridating solutions each contained $125 \mathrm{mg} \mathrm{F}^{-}$per $100 \mathrm{~mL}$ solution. Initial $\mathrm{pH}$ was 5.5 and initial temperature was $20^{\circ} \mathrm{C}$. Calcium fluoride $\left(\mathrm{CaF}_{2}\right)$ formation was measured indirectly by comparing the percentages of $\mathrm{F}$ ions bound by the apatites. Apatite fluoridation was measured

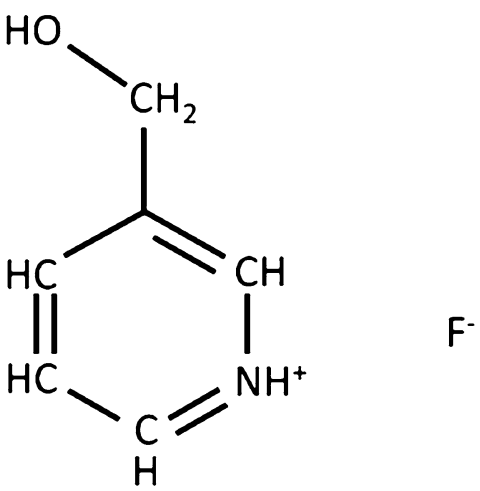

\section{3-pyridinemethanol, hydrofluoride}

$$
\begin{gathered}
\text { nicomethanol fluorhydrate }\left(\mathrm{C}_{6} \mathrm{H}_{8} \mathrm{NOF}\right) \\
\text { or } \\
\text { nicomethanol hydrofluoride }\left(\mathrm{C}_{6} \mathrm{H}_{8} \mathrm{NOF}\right)
\end{gathered}
$$

Fig. 1 Chemical structure of nicomethanol hydrofluoride (NH)

by infrared spectroscopy according to the methodology described by Okazaki (1983). Absorption intensity was measured for the $\mathrm{OH}^{-}, \mathrm{PO}_{4}{ }^{-}, \mathrm{CO}_{3}{ }^{2-}$ ions and the ratios $\mathrm{CO}_{3}{ }^{2-} / \mathrm{PO}_{4}{ }^{-}$and $\mathrm{OH}^{-} / \mathrm{PO}_{4}{ }^{-}$were calculated.

\section{F uptake measurements by infrared spectroscopy and X-ray diffraction}

F uptake at the surface of dental enamel was measured after treatment with either $\mathrm{NH}$ or $\mathrm{NaF}$, both containing a proportion of $220 \mathrm{mg} \mathrm{F}^{-}$per $100 \mathrm{~mL}$ solution. A test sample of $100 \mathrm{mg}$ of natural dihydroxyapatite was placed under ultrasonic vibration in the presence of $10 \mathrm{~mL}$ of the solution to be tested and $10 \mathrm{~mL}$ of buffer solution at $\mathrm{pH} 5.5$. After 1 min of contact, the reaction mixture was filtered to separate the fluoroapatite precipitate. The filtrate underwent the same treatment after 2 min and a new fluoroapatite precipitate was obtained. Successive filtrates after 3, 10,15 and $30 \mathrm{~min}$ of contact, respectively, were isolated. The percentage of formed fluoroapatites was assessed.

Qualitative and quantitative F uptakes by enamel surfaces were measured by quantifying fluoride ions using infrared spectrophotometry (Perkin Elmer spectrophotometer, model 521) and X-ray diffraction (Guigner-de Wolff chamber, Nonius brand) (Baud and Bang 1970; Okazaki 1983).

\section{F uptake measurements in the presence of siliglycol}

$\mathrm{F}$ uptakes at the surface of a synthetic carbonated apatite (structural analogue of dental enamel) were measured after 
treatment with $\mathrm{NH}$ alone or $\mathrm{NH}$ combined with siliglycol (Featherstone et al. 1990). The solution of NH was prepared with $4.25 \mathrm{~mL}$ of $\mathrm{NH}$ and $100 \mathrm{~mL}$ of distilled water. A solution of $0.5 \mathrm{~mL}$ of siliglycol was included to prepare the "combined" solution.

A sample of $500 \mathrm{mg}$ of apatite was in contact with each of the tested solutions for $3 \mathrm{~h}$. Fluoridation rate after $3 \mathrm{~h}$ was so high that the time of contact was reduced to 5 and 30 min. F uptake was measured at each time point.

Since the extent of F uptake was still high, the tested solutions were diluted to a factor of 10 . Synthetic apatite was treated for $3 \mathrm{~min}$, rinsed with water, left in contact with the solution for $1 \mathrm{~h}$, in a humid environment, to allow potential fluoridation to occur and rinsed again before measuring $\mathrm{F}$ uptake.

Siliglycol "mechanical" retention was evaluated by a bonding test on Teflon plates. Two solutions of NH diluted by a factor of 10 were tested, with or without siliglycol. The Teflon plates were immersed in the tested solution, removed from the solution and left to dry for $1 \mathrm{~min}$. The plates were then rinsed in an agitated solution, in which $\mathrm{F}$ uptake was measured.

\section{Clinical investigations}

Some of the studies have been conducted in the early 1980's and at that time, in France, ethical approval was not needed.

$\mathrm{NH}$ impact on salivary $\mathrm{pH}$ was investigated in subjects who had taken the product in mouthwash form $\left(250 \mathrm{mg} \mathrm{F}^{-}\right.$ per $100 \mathrm{~mL}$ solution). This effect was compared to the effect of a placebo and of a control (nicomethanol solution, with the same molar concentration as the tested solution). The assessment of $\mathrm{pH}$ change at several time points $(5,15$ and $30 \mathrm{~min}$ ) was the primary study endpoint.
A total of 12 healthy human volunteers were enrolled (no gingivitis diagnosed and systematic diseases diagnosed as well). A sample of $2-3 \mathrm{~mL}$ of saliva was taken at baseline. Each subject had two mouthrinses of $60 \mathrm{~s}$ each, separated by $1 \mathrm{~min}$, using $15 \mathrm{~mL}$ of solution. A wash-out period (at least 3 days) separated the testing of the two different solutions. At the end of each mouthrinse, the content of the oral liquid was expectorated. Saliva samples were taken at 5, 15 and $30 \mathrm{~min}$ after the two 60-s mouthrinses, and $\mathrm{pH}$ measurements were performed on $2 \mathrm{~mL}$ of saliva mixed with $0.5 \mathrm{~mL}$ of glucose of neutral $\mathrm{pH}$, every hour for $6 \mathrm{~h}(\mathrm{pH}$ meter Digital Metrohm Herisau). Data were analysed using the one-way analysis of variance test.

\section{Results}

\section{In vitro investigations}

\section{Calcium fluoride formation}

With the control solution $(\mathrm{NaCl}), \mathrm{F}$ uptake was $0.015 \%$ on dental enamel surfaces and $0.05 \%$ on synthetic apatite surfaces. F uptake was greater or higher with $\mathrm{NH}$ than with $\mathrm{NaF}$ solution, both on dental enamel (0.75 vs $0.06 \%)$ and on synthetic apatite (23.1 vs $1.2 \%)$. Overall, F uptake was approximately 12 times greater on dental enamel and 19 times greater on synthetic apatite, with $\mathrm{NH}$ compared to $\mathrm{NaF}$.

Calcium fluoride $\left(\mathrm{CaF}_{2}\right)$ formation was greater with $\mathrm{NH}$ than with $\mathrm{NaF}$ solution, as indicated by the percentages of F ions bound by the synthetic apatite (Fig. 2).
Fig. 2 Percentage of fluoride ions $\left(\mathrm{F}^{-}\right)$bound by variable quantities of synthetic apatite (100 and $200 \mathrm{mg}$ ). min minute, $\mathrm{NaF}$ sodium fluoride, $\mathrm{NH}$ nicomethanol hydrofluoride

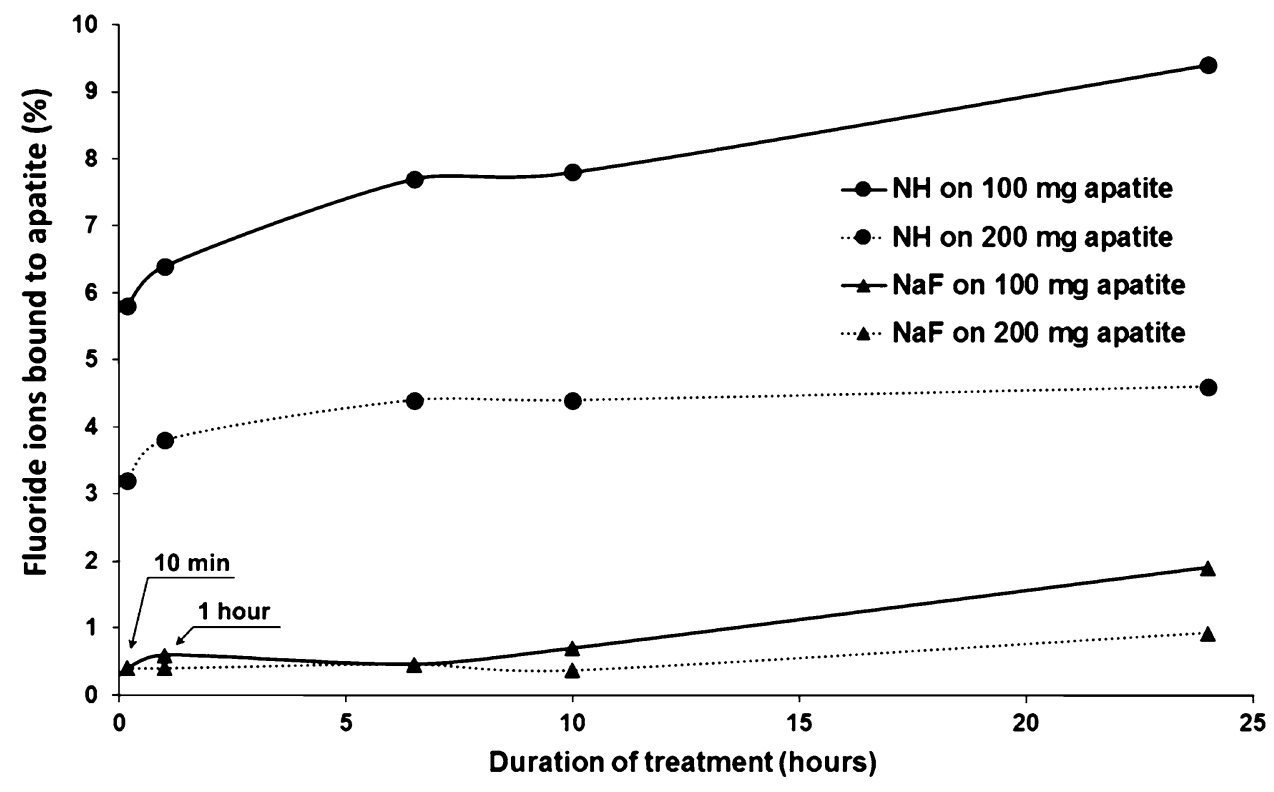


Fig. 3 Fluoridation of synthetic apatite after treatment with solutions of nicomethanol hydrofluoride $(\mathrm{NH})$ and sodium fluoride $(\mathrm{NaF})$ : data obtained by infrared spectroscopy. $\mathrm{NaF}$ sodium fluoride, $\mathrm{NH}$ nicomethanol hydrofluoride
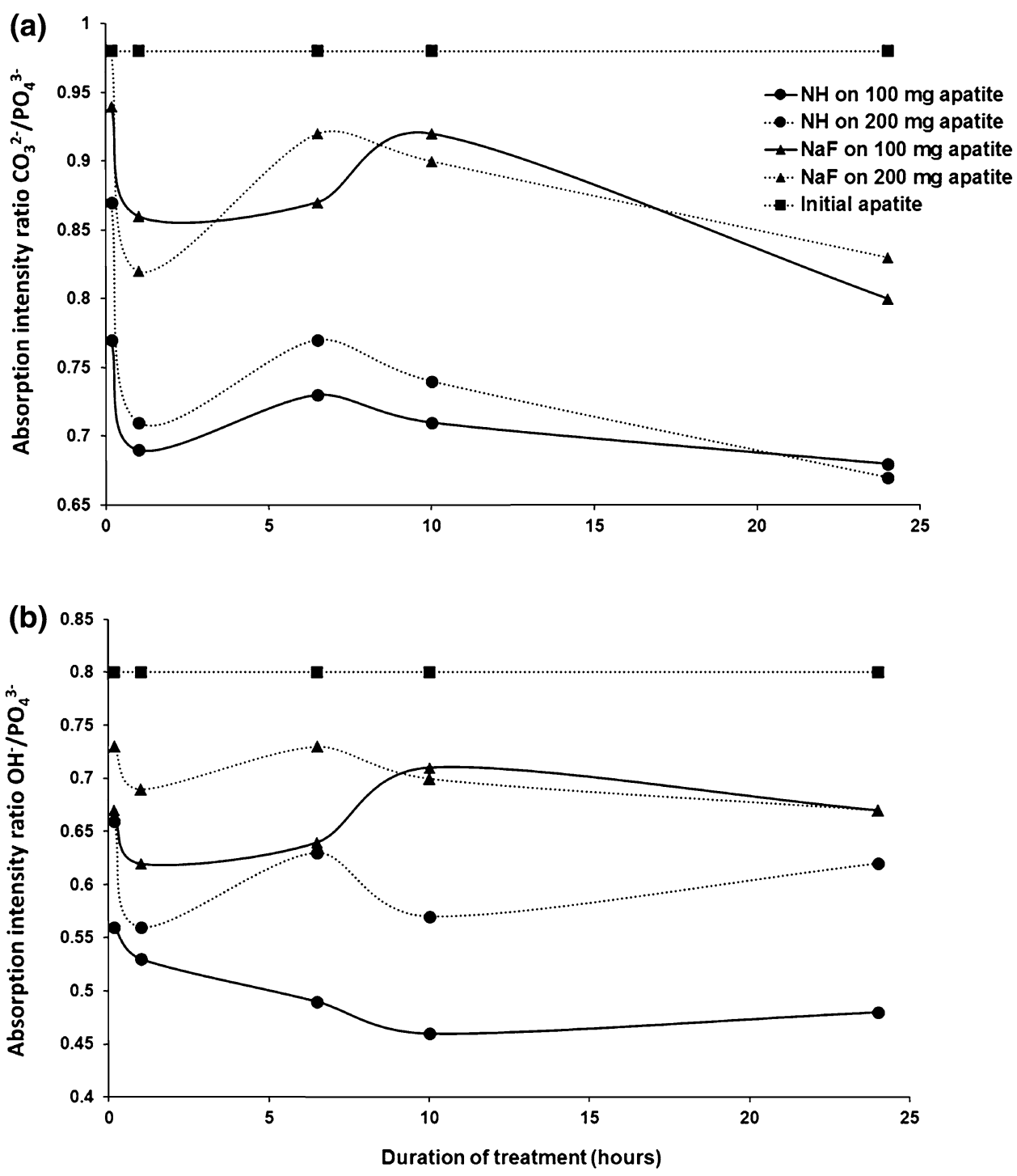

Investigations using infrared spectroscopy showed a reduction of the ratios of $\mathrm{CO}_{3}{ }^{2-} / \mathrm{PO}_{4}{ }^{-}$and $\mathrm{OH}^{-} / \mathrm{PO}_{4}{ }^{-}$, indicating a decrease in the content in $\mathrm{OH}^{-}$and $\mathrm{CO}^{2-}$ ions in the synthetic apatite (Fig. 3).

\section{F uptake measurements}

F uptake was greater with $\mathrm{NH}$ than with $\mathrm{NaF}$ from the first minute of contact. At 1 min of contact, $\mathrm{F}$ uptake was $41.0 \%$ with $\mathrm{NH}$ vs $7.6 \%$ with $\mathrm{NaF}$ (Fig. 4). At 3 min of contact, $\mathrm{F}$ uptake was $91.5 \%$ with $\mathrm{NH}$ vs $15.4 \%$ with $\mathrm{NaF}$. Overall, bonding of $\mathrm{F}$ ions to the substrate was faster and quantitatively superior with $\mathrm{NH}$ than with $\mathrm{NaF}(\times 5.4$ at $1 \mathrm{~min}$ of contact, and $\times 5.9$ at $3 \mathrm{~min}$ of contact).
$F$ uptake measurements in the presence of siliglycol

At $3 \mathrm{~h}$ of contact, a marked $\mathrm{F}$ uptake was observed $(4.75-5 \%)$. This quantity is higher than the maximum theoretical quantity of $\mathrm{F}$ uptake $(3.8 \%)$ assuming a complete fluoridation of the apatite $\left(\mathrm{Ca}_{10}\left(\mathrm{PO}_{4}\right)_{6}(\mathrm{OH})_{2}-\right.$ $\left.\mathrm{Ca}_{10}\left(\mathrm{PO}_{4}\right)_{6} \mathrm{~F}_{2}\right)$.

Tests on the diluted solutions showed a similar F uptake after 3 min of treatment with $\mathrm{NH}$ alone and with the combination of $\mathrm{NH}$ and siliglycol. After rinsing the apatite with water, F uptake was $13.2 \%$ higher in the sample treated with the combined solution rather than $\mathrm{NH}$ alone (0.302 vs 0.262 , Table 1$)$.

The bonding test on Teflon plates showed a greater $\mathrm{F}$ uptake after immersion into the solution with siliglycol $\left(2.7410^{-5} \mathrm{~mol} / \mathrm{L}\right)$ vs the fluoridated solution without 
Fig. 4 Formation of fluoroapatite after treatment with nicomethanol hydrofluoride $(\mathrm{NH})$ and sodium fluoride (NaF). $\mathrm{NaF}$ sodium fluoride, $\mathrm{NH}$ nicomethanol hydrofluoride
Table 1 Percentage of fluoride uptake on synthetic apatite
Fluoroapatite formation (\%)

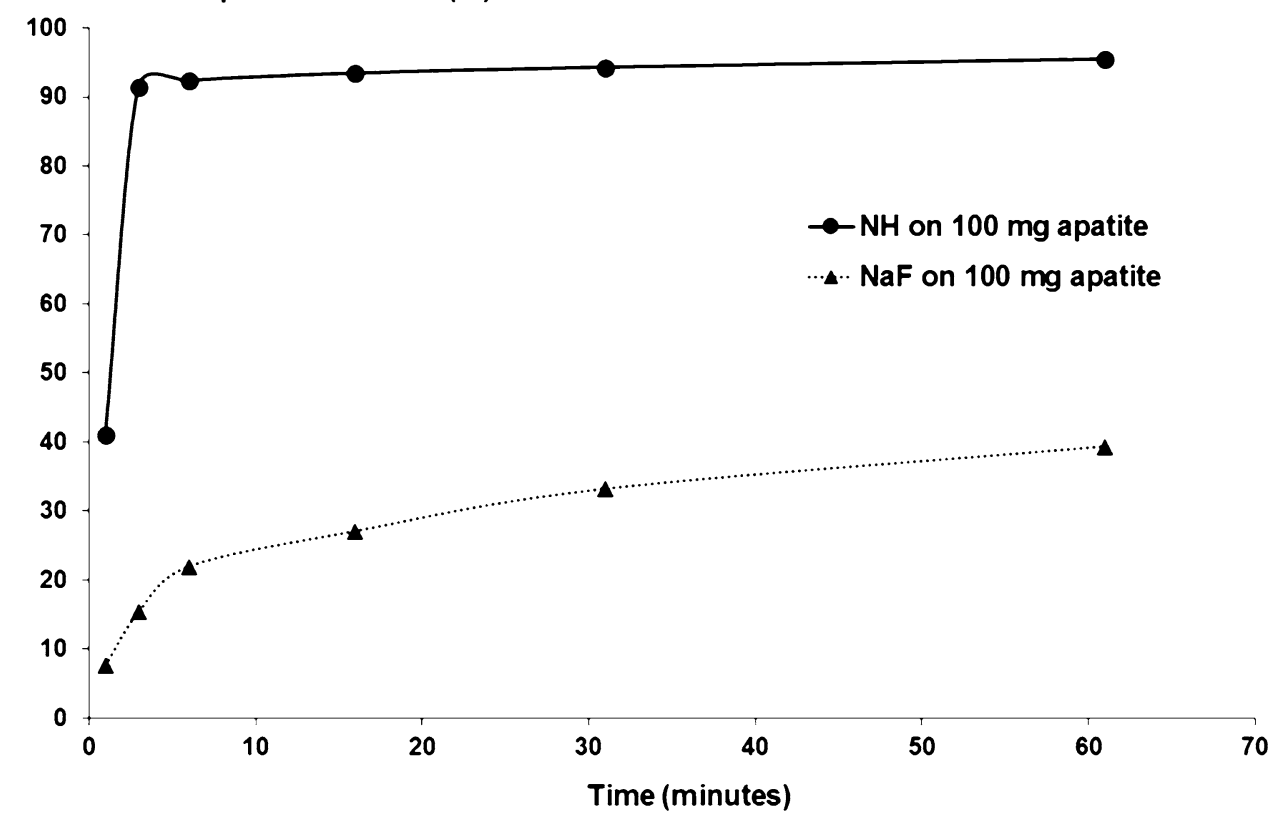

\begin{tabular}{llll}
\hline Solution & \% Fluoride measure I & \% Fluoride measure II & \% Fluoride mean value \\
\hline $\mathrm{NH}$ & 0.264 & 0.260 & 0.262 \\
$\mathrm{NH}+$ siliglycol & 0.306 & 0.299 & 0.302 \\
\hline
\end{tabular}

The experiment was performed twice (measure I and measure II) and the mean value was considered for analysis

$\mathrm{NH}$ nicomethanol hydrofluoride siliglycol $\left(1.8710^{-5} \mathrm{~mol} / \mathrm{L}\right)$. F uptake increased by approximately $30 \%$ in the presence of siliglycol.

\section{Clinical investigations}

For healthy human volunteers, the $\mathrm{pH}$ reduction following two mouthrinses was smaller with $\mathrm{NH}$ than with the control solution (nicomethanol alone) or with the placebo. A marked inhibitory effect of $\mathrm{NH}$ on salivary glycolysis was observed 5 min after the mouthrinse (Figs. 4, 5). After 15 and $30 \mathrm{~min}$, the effect appeared to be less pronounced but remained statistically significant ( $p<0.05$, Fig. 5).

\section{Discussion}

Treatment with $\mathrm{NH}$ alone was associated with a greater and faster $\mathrm{F}$ uptake on dental enamel surfaces or synthetic apatite surfaces than treatment with $\mathrm{NaF}$. The addition of the coating agent siliglycol improved $\mathrm{F}$ uptake even further. NH was also shown to exert a strong and sustained inhibitory effect on salivary glycolysis in healthy human volunteers. All together, these findings support the anticaries activity of $\mathrm{NH}$.

Fluoridation rate has been recognised as an important aspect of the caries preventive action of $\mathrm{F}$ (Galuscan et al. 2003). Amine derivatives in the form of hydrofluoride are excellent carriers for $\mathrm{F}$ ions, which can be exchanged with hydroxyl groups from the hydroxyapatite of enamel. In vitro experiments showed that this exchange is very fast, with $50 \%$ of $\mathrm{F}$ ions being picked up by the apatite after 1 min of interaction.

The faster $\mathrm{F}$ uptake with $\mathrm{NH}$ than with $\mathrm{NaF}$ could be explained by the molecular structure of the compound. The presence of both a hydrophilic part (amine group) and hydrophobic part (hydrocarbon chain) in amine fluorides reduces surface tension of liquids and increases the affinity of $F$ to the enamel surface. As a result, more $F$ ions are available on the enamel surface, providing better conditions for F uptake.

F uptake is not only faster but also greater with $\mathrm{NH}$ than with mineral fluorides, i.e. approximately 5 times greater 

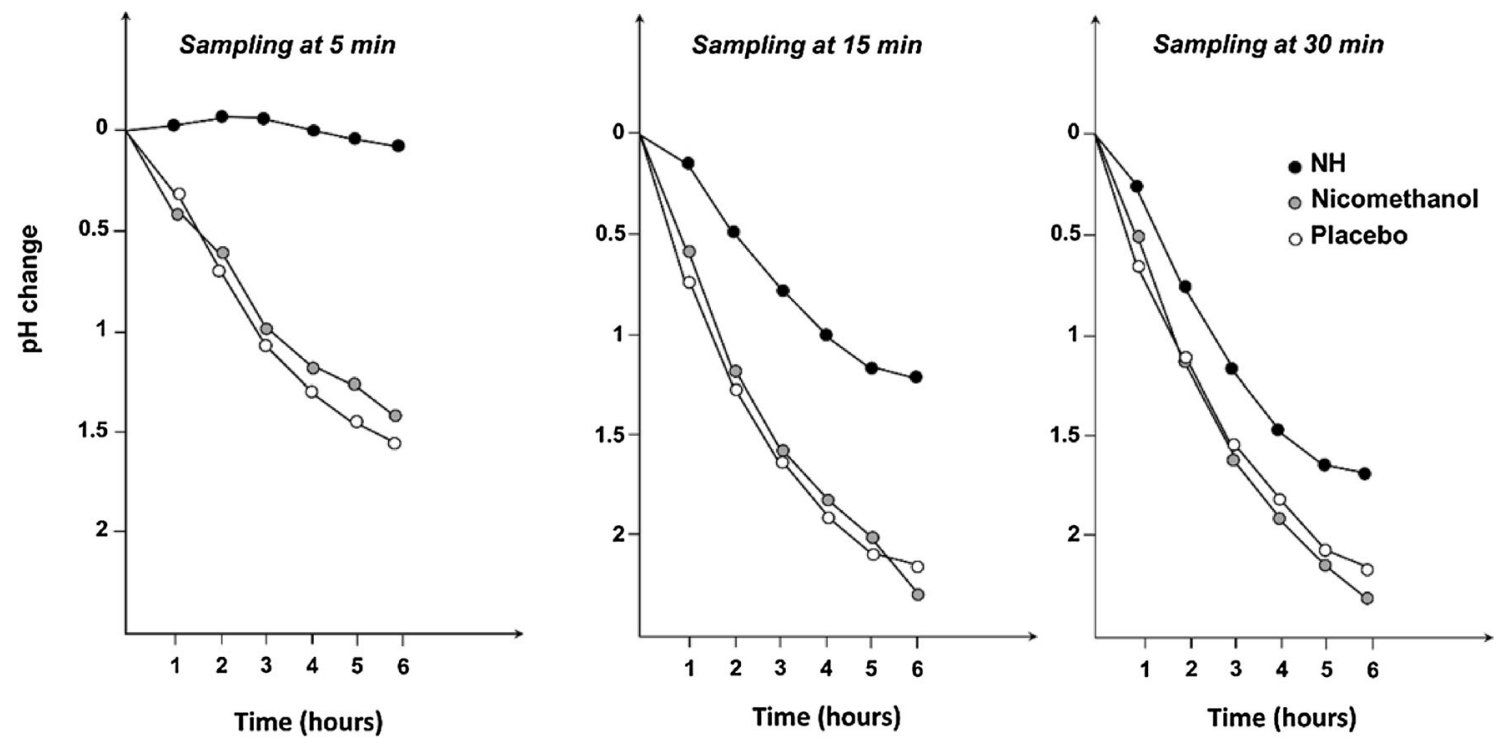

Fig. 5 Change in salivary $\mathrm{pH}$ following two mouthrinses: effect of treatment and time of sampling $(5,15$ and 30 min after second mouthrinse). min minute, $\mathrm{NH}$ nicomethanol hydrofluoride

compared to $\mathrm{NaF}$ after 1 min of contact. Apatite fluoridation was clearly shown by infrared spectroscopy, which revealed a decrease of $\mathrm{OH}^{-}$and $\mathrm{CO}_{3}{ }^{2-}$ ions in the apatite. $\mathrm{F}$ uptake obtained with $\mathrm{NH}$ was higher than expected with a total exchange of hydroxyl ions by fluoride ions, suggesting $\mathrm{CaF}_{2}$ formation.

The formation of $\mathrm{CaF}_{2}$ was confirmed by an in vitro study (Lacout 2011) that investigated the fluoridation capacity of different fluoridated solutions compared to a control solution of $\mathrm{NaF}\left(250 \mathrm{ppm}\right.$ of $\left.\mathrm{F}^{-}\right)$at a $\mathrm{pH} 4.33$. Synthetic hydroxyapatite discs (similar to dental enamel) were treated with 6 mouthrinses and a control solution, with a contact duration of 2,4 and $6 \mathrm{~h}$ corresponding to a cumulative 2-min daily rinsing of mouthrinse used for 2, 4 and 6 months. Fluoridation was more effective with the solutions containing an organic fluoride $(\mathrm{NH})$ compared to the control NaF-based solution, and this superiority increased with contact duration. Calcium fluoride structure was confirmed by X-ray diffraction.

The extent of fluoridation obtained with organic $F$ was therefore caused by a combination of hydroxyapatite fluoridation and formation of $\mathrm{CaF}_{2}$ (Trombe et al. 1982; Galuscan et al. 2003).

It was suggested that the formation of $\mathrm{CaF}_{2}$ may be involved in mechanisms of surface remineralisation within dentine, playing a desensitising role by blocking dentinal tubules (Trombe et al. 1982), but also a protective role by decreasing the solubility of enamel in an acidic environment. In support of this hypothesis, in vitro studies on human teeth showed that $\mathrm{NH}$ decreased the enamel solubility to a greater extent than mineral fluorides (Vezin et al. 1985; Tadmor et al. 1989). As an illustration, the quantity of calcium and phosphorus collected after acid attack simulation (hydrochloric acid for $4 \mathrm{~h}$ ) on healthy teeth was lower after treatment with $\mathrm{NH}$ rather than $\mathrm{NaF}$ (Vezin et al. 1985).

The decreased solubility of enamel was primarily supported by the formation of fluoroapatite and $\mathrm{CaF}_{2}$, which are more resistant to acid attack than hydroxyapatite.

Calcium fluoride, as a protective, adhesive layer on tooth enamel, represents a long-lasting source of $\mathrm{F}$ ions. Acid attacks cause these ions to be released, which promotes remineralisation (Galuscan et al. 2003). The formation of fluoroapatite and $\mathrm{CaF}_{2}$ enables dental enamel to resist acid attacks for a longer period of time. A pH cycling study confirmed the effects of $\mathrm{NH}$ on de- and remineralisation phases of advanced $(>150 \mu \mathrm{m})$ enamel lesions (ten Cate et al. 2008). $\mathrm{NH}$ was compared to $\mathrm{NaF}$ at variable concentrations of fluoride $(0-5000 \mathrm{ppm} \mathrm{F})$, and to a fluoride-free control solution. Treatments with $5000 \mathrm{ppm} \mathrm{F}$ both significantly enhanced remineralisation and inhibited demineralisation when compared to treatments with $1500 \mathrm{ppm}$ F. The calcium apposition and loss were similar between the two sources of fluoride, except slight differences in favour of $\mathrm{NH}$ for demineralisation at $500 \mathrm{ppm}$ and of remineralisation at $5000 \mathrm{ppm}$. At equal concentrations, the calcium loss/gain ratios were more favourable with $\mathrm{NH}$ than with $\mathrm{NaF}$, reflecting a better balance between the deand remineralisation phases of enamel lesions with $\mathrm{NH}$.

The study conducted in 12 healthy human subjects showed that mouthrinses with NH resulted in a stronger inhibition of salivary glycolysis than the placebo or control solution (nicomethanol alone). The inhibitory effect was efficient within the first $5 \mathrm{~min}$ and remained significant for 
$30 \mathrm{~min}$ after the rinses. This anti-glycolytic activity strengthened the anti-caries role of $\mathrm{NH}$.

The coating agent siliglycol was able to prevent the immediate elimination of fluoride following rinsing with water. This effect was confirmed by the bonding test performed on Teflon plates, which showed that the coating agent ensured a greater retention $(30 \%)$ of $\mathrm{NH}$. The synergetic effect of the $\mathrm{NH} /$ siliglycol combination was illustrated by the significant increase $(13 \%)$ in $\mathrm{F}$ uptake after rinsing the apatite with water, in comparison to $\mathrm{NH}$ alone.

Siliglycol was shown to prevent bacterial adhesion on the surface of synthetic apatite (Dorignac 1996), on dental enamel (Roques et al. 2001) and on a model of the oral cavity (Zampatti et al. 1994). These findings are relevant considering that dental plaque control plays a key role in oral hygiene, especially in the prevention of caries (Roques et al. 2001), and that the first step of the plaque formation is the adhesion of bacteria belonging to the Streptococcus mutans group to the tooth surfaces (Furiga et al. 2008).

Using calibrated discs of dental composite (Heliomo$\left.\operatorname{lar}^{\circledR}\right)$, which has been shown to promote microorganism adhesion, the quantity of bacteria was shown to increase as the quantity of siliglycol covering the disks decreased (Dorignac 1996). Siliglycol seemed to be an effective interface for preventing bacterial adhesion to its support surface and remained sufficiently present on the support material surface to ensure that the material was protected from acid attack (Dorignac 1996).

Similar results were obtained with a toothpaste combining $\mathrm{NH}$ and siliglycol for the prevention of $S$. mutans adhesion to the enamel surfaces (Roques et al. 2001). The toothpaste treatment combining $\mathrm{NH}$ and siliglycol led to a larger decrease in the number of adherent bacteria in comparison to $\mathrm{NH}$ placebo, siliglycol placebo and total placebo $(\mathrm{p} \leq 0.01)$. The duration of treatment $(30 \mathrm{~s}$ vs $5 \mathrm{~min}$ ) did not affect the results, indicating a rapid effect of the toothpaste with little or no time dependency. These results were confirmed using an in vitro artificial mouth model (Roques et al. 2001).

Similar experiments were conducted using an artificial model of the oral cavity, which was based on the continuous irrigation of bovine tooth samples with artificial saliva (Zampatti et al. 1994). Treatment with a toothpaste containing $\mathrm{NH}$ and siliglycol was shown to inhibit bacterial colonisation on enamel surfaces. Overall, siliglycol was found to be an effective coating agent that acted with $\mathrm{NH}$ to condition the surface of the tooth. The results illustrated the two main roles of the toothpaste: the elimination of plaque during brushing and the prevention of the formation of new plaque, both on permanent and primary teeth.

The synthesis of insoluble glucan from glucosyltransferases of Streptococcus spp. significantly contribute to bacterial colonisation, making this enzymatic activity a potential target to control the formation and development of oral biofilms. The ability of $\mathrm{NH}(10.2 \mathrm{mg} / \mathrm{mL})$ to impair multispecies biofilm formation (Guggenheim model) was investigated by measuring the quantity of sugars released and the quantity of insoluble glucans synthesised (Furiga et al. 2014). Results are presented as percentage of enzymatic activity with respect to controls (without any compound). $\mathrm{NH}$ showed a significant inhibitory activity of $20.6 \%$ against the quantity of sugars released $(p<0.01)$, but no effect on insoluble glucan synthesis was observed (Furiga et al. 2014).

\section{Conclusions}

$\mathrm{NH}$ has intrinsic properties capable of promoting anticaries protection through various mechanisms. The present in vitro experiments showed a greater and faster $\mathrm{F}$ uptake to dental enamel or synthetic apatite treated with $\mathrm{NH}$ compared to sodium fluoride, thus suggesting an important role for $\mathrm{NH}$ during remineralisation phases in enabling better resistance to aggressions (such as acid dissolution) and promoting the fixation of $\mathrm{F}$ ions within the dental enamel. These properties have been observed from concentrations of $250 \mathrm{ppm}$ of $\mathrm{F}$ ions and provide a protective effect on global dental structures (enamel and dentine). Moreover, NH was shown to exert a strong and sustained inhibitory effect on salivary glycolysis in healthy human volunteers, further supporting the conclusion that $\mathrm{NH}$ has an anti-caries function. The combination of $\mathrm{NH}$ with the covering agent siliglycol has also been evaluated. In vitro experiments using synthetic apatite as an analogue of dental enamel showed a marked increase in $\mathrm{F}$ uptake on apatite surfaces in the samples treated with a combination of $\mathrm{NH}$ and siliglycol as compared to $\mathrm{NH}$ alone. This agent therefore provides higher resistance to acid attacks and the control/inhibition of dental biofilm development.

Acknowledgements The author would like to thank Pierre Fabre Oral Care medical department for providing technical internal data. Pierre Fabre Médicament, Castres, France, provided financial support for the manuscript preparation and gratefully acknowledges Scinopsis Medical Writing for their assistance. The author did not receive any financial support for the writing of this manuscript.

\section{Compliance with ethical standards}

Conflict of interest N. Sharkov is a member of the scientific committee held by Pierre Fabre Oral Care.

Ethical approval Some of the studies have been conducted in the early 1980's and at that time, in France, ethical approval was not needed. 
Open Access This article is distributed under the terms of the Creative Commons Attribution 4.0 International License (http://crea tivecommons.org/licenses/by/4.0/), which permits unrestricted use, distribution, and reproduction in any medium, provided you give appropriate credit to the original author(s) and the source, provide a link to the Creative Commons license, and indicate if changes were made.

\section{References}

Banoczy J, Rugg-Gunn A. Epidemiology and prevention of dental caries. Acta Med Acad. 2013;42(2):105-7. doi:10.5644/ama2006-124.78.

Barbakow F, Cornec S, Rozencweig D, Vadot J. Enamel fluoride content after using amine fluoride- or monofluorophosphate-sodium fluoride-dentifrices. ASDC J Dent Child. 1983;50(3):186-91.

Baud CA, Bang S. Electron probe and X-ray diffraction microanalyses of human enamel treated in vitro by fluoride solution. Caries Res. 1970;4(1):1-13.

Bratthall D, Hansel-Petersson G, Sundberg H. Reasons for the caries decline: what do the experts believe? Eur J Oral Sci. 1996;104(4 Pt 2):416-22 (discussion 23-5, 30-2).

Byeon SM, Lee MH, Bae TS. The effect of different fluoride application methods on the remineralization of initial carious lesions. Restor Dent Endod. 2016;41(2):121-9. doi:10.5395/rde. 2016.41.2.121.

Cahen PM, Frank RM, Turlot JC, Jung MT. Comparative unsupervised clinical trial on caries inhibition effect of monofluorophosphate and amine fluoride dentifrices after 3 years in Strasbourg, France. Commun Dent Oral Epidemiol. 1982;10(5):238-41.

Carey CM. Focus on fluorides: update on the use of fluoride for the prevention of dental caries. J Evid Based Dent Pract. 2014;14(Suppl):95-102. doi:10.1016/j.jebdp.2014.02.004.

Cury JA, Tenuta LM, Ribeiro CC, Leme AFP. The importance of fluoride dentifrices to the current dental caries prevalence in Brazil. Braz Dent J. 2004;15(3):167-74. doi:10.1590/S010364402004000300001.

Dorignac G. Role of siliglycol on bacterial adhesion on composite dental surfaces. Bordeaux: UFR d'Odontologie, Département d'Odontologie Pédiatrique et laboratoire de Microbiologie buccale. 1996.

Featherstone JD, Glena R, Shariati M, Shields CP. Dependence of in vitro demineralization of apatite and remineralization of dental enamel on fluoride concentration. J Dent Res. 1990;69:620-5. doi: 10.1177/00220345900690S121 (discussion 34-6).

Furiga A, Lonvaud-Funel A, Dorignac G, Badet C. In vitro antibacterial and anti-adherence effects of natural polyphenolic compounds on oral bacteria. J Appl Microbiol. 2008;105(5):1470-6. doi:10.1111/j.1365-2672.2008.03882.x.

Furiga A, Roques C, Badet C. Preventive effects of an original combination of grape seed polyphenols with amine fluoride on dental biofilm formation and oxidative damage by oral bacteria. J Appl Microbiol. 2014;116(4):761-71. doi:10.1111/jam.12395.

Galuscan A, Podariu AC, Jumanca D. The decreasing of carious index by using toothpaste based on amine fluoride. Oral Health Dent Man Black Sea Ctries. 2003;1:42-3.

Kimura I, Tsubota T, Ohnoshi T, et al. In vivo antitumor activity of neocarzinostatin (NCS)-tumor antibody conjugate against a transplantable human leukemia cell line (BALL-1). Jpn J Clin Oncol. 1983;13(2):425-33.

Lacout JL. Fluoridation with mouthrinses: effects of different fluoride compounds and the solution pH. Rev Odont Stomat. 2011;40:192-203.

Lata S, Varghese NO, Varughese JM. Remineralization potential of fluoride and amorphous calcium phosphate-casein phospho peptide on enamel lesions: an in vitro comparative evaluation. J Conserv Dent JCD. 2010;13(1):42-6. doi:10.4103/0972-0707.62634.

Madlena M. Experiences with amine fluoride containing products in the management of dental hard tissue lesions focusing on Hungarian studies: a review. Acta Med Acad. 2013;42(2):189-97. doi:10.5644/ama2006-124.86.

Marinho VC. Cochrane reviews of randomized trials of fluoride therapies for preventing dental caries. Eur Arch Paediatr Dent. 2009; 10(3):183-91.

Marinho VC, Worthington HV, Walsh T, Clarkson JE. Fluoride varnishes for preventing dental caries in children and adolescents. Cochrane Database Syst Rev. 2013;(7):CD002279. doi:10. 1002/14651858.CD002279.pub2.

Markovic N, Muratbegovic AA, Kobaslija S, et al. Caries prevalence of children and adolescents in Bosnia and Herzegovina. Acta Med Acad. 2013;42(2):108-16. doi:10.5644/ama2006-124.79.

Muhlemann HR, Schait A, Konig KG. Fluorine uptake of enamel and animal caries inhibition of topical sodium fluoride and aminefluorides at low fluoride concentrations. Helv Odontol Acta. 1968;12(2):61-6.

Okazaki M. F- $\mathrm{CO}_{3}(2-)$-interaction in IR spectra of fluoridated $\mathrm{CO}_{3}$ apatites. Calcif Tissue Int. 1983;35(1):78-81.

Patel R. The state of oral health in Europe (Report commissioned by the Platform for Better Oral Health in Europe). 2012.

Priyadarshini S, Raghu R, Shetty A, et al. Effect of organic versus inorganic fluoride on enamel microhardness: an in vitro study. J Conserv Dent JCD. 2013;16(3):203-7. doi:10.4103/0972-0707. 111314.

Roques C, Rochd T, Landru MM, Jomard P, Federlin M. In vitro colonization of dental surface by streptococcus mutans: changes induced by preventative and/or curative treatment with a toothpaste containing $1 \%$ siliglycol. J Parodontol Impl Orale 2001;20(3):219-26.

Rugg-Gunn A. Dental caries: strategies to control this preventable disease. Acta Med Acad. 2013;42(2):117-30. doi:10.5644/ ama2006-124.80.

Rugg-Gunn A, Banoczy J. Fluoride toothpastes and fluoride mouthrinses for home use. Acta Med Acad. 2013;42(2): 168-78. doi:10.5644/ama2006-124.84.

Shani S, Freiedman M, Steinberg D. Relation between surface activity and antibacterial activity of amine-fluorides. Int $\mathrm{J}$ Pharm. 1996;131(1):33-9.

Szilagyi J. Contribution to the study of reactivity of tooth enamel and synthetic apatites in the presence of fluoride ions: reactivity mechanisms. Toulouse: Institut National Polytechnique de Toulouse; 1981.

Tadmor E, Poitou P, Gedalia I. In vitro acid decalcification of human surface enamel pretreated with toothpaste slurries. J Oral Rehabil. 1989;16(6):613-6.

ten Cate JM. Current concepts on the theories of the mechanism of action of fluoride. Acta Odontol Scand. 1999;57(6):325-9.

ten Cate JM, Buijs MJ, Miller CC, Exterkate RA. Elevated fluoride products enhance remineralization of advanced enamel lesions. J Dent Res. 2008;87(10):943-7.

Tenuta LM, Cury JA. Fluoride: its role in dentistry. Braz Oral Res. 2010;24(Suppl 1):9-17.

Trombe JC, Szilagyi J, Rey C, et al. On the substitution of OH-ions from carbonated hydroxyapatite by fluoride ions. C R Acad Sci. 1982;294:575-8.

Vezin JC, Bounoure GM, Mondain J, Poitou P. Reduction of the solubility of enamel following treatment with nicomethanol hydrofluoride. Pharm Acta Helv. 1985;60(5-6):145-8.

Zampatti O, Roques C, Michel G. An in vitro mouth model to test antiplaque agents: preliminary studies using a toothpaste containing chlorhexidine. Caries Res. 1994;28(1):35-42. 